Article

\title{
Toward An Ethics of Reciprocity: Ethnobotanical Knowledge and Medicinal Plants as Cancer Therapies
}

\section{John Charles Ryan}

School of Communications and Arts, Edith Cowan University, room 17.206, 2 Bradford Street, Mount Lawley, WA 6050, Australia; E-Mail: john.ryan@ecu.edu.au; Tel.: +61-08-9370-6454

External Editor: Albrecht Classen

Received: 11 September 2014; in revised form: 5 October 2014 / Accepted: 17 October 2014 / Published: 29 October 2014

\begin{abstract}
This article develops a reciprocity ethics of the environment through a discussion of ethnobotanical medicines used in the treatment of cancer. The moral virtue of reciprocity, defined as the returning of good when good is received or anticipated, is central to the posthumanist rethinking of human relationships to the plant world. As herbal medicines are used progressively more around the globe and as plant diversity decreases as a result of habitat loss and climate change, an ethics of reciprocity should be a concern for environmental philosophers and conservationists. Aldo Leopold's land ethic and J. Baird Callicott's distinction between deontological and prudential environmental

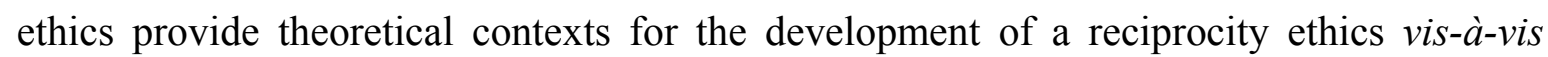
ethnobotanical species. While this article does not necessarily specify modes or forms of reciprocity, it does outline some of the more prominent ethnobotanical species used in the treatment of cancer, including those from Native American, African, Chinese, and Indian traditions. In the form of a dialogue between the fields of ethnobotany, herbal medicine, and environmental philosophy, this article presents a position from which further articulations of reciprocity can be developed, particularly those involving the rights of indigenous cultures and plants.
\end{abstract}

Keywords: ethnobotanical knowledge; medicinal plants; ethics; reciprocity; Leopold; Callicott; Gaian theory; Chinese medicine; Ayurveda; Native American etiology 


\section{Introduction}

For a posthumanist relationship to the natural world - one that treats the environment as an active and creative agent to be worked with rather than a material, substance, or sight to be worked over - the moral virtue of reciprocity is essential. The need for posthumanist perspectives on the natural world is pressingly evident in humanity's interactions with plant life and, more specifically, with medicinal herbs - both cultivated on farms and crafted from the wild. Increased demands have been placed on wild populations of plants to supply herbal medicines that cannot be derived from cultivated species. The number of Americans using herbal medicines between 1990 and 1997 increased 380\% [1]. In 2002, herbal therapy was the leading CAM (complementary and alternative medicine) modality, consumed by 38 million U.S. adults. In 1997, 12.1\% of the U.S. population used herbal medicine, whereas, by 2002, this figure increased to $18.6 \%$ [2]. Moreover, sales of herbal medicines skyrocketed from \$200 million in 1988 to \$3.5 billion in 1997 and \$4.4 billion in 2005. The naturopathic doctor Michael Murray has fittingly pointed to a "herbal renaissance" resulting from advances in pharmacological techniques, increased scientific knowledge of medicinal compounds, and enhanced public acceptance of natural, or complementary, therapies [3]. Ethnobotanical medicines have been pivotal to the renaissance identified by Murray. Species, such as jimson weed and devil's club discussed later in this article, are modern medicines (or plants perceived to have certain medicinal and toxic properties) with documented therapeutic application in traditional cultures. Hence, ethnobotanical knowledge can be characterized through the dialogue or exchange between traditional or indigenous knowledge of plants and contemporary, science-based understandings of herbs and etiology [4].

Using ethnobotanical medicines from various global traditions for the treatment of cancer as examples, this article examines the utilitarian and anthropocentric ethics surrounding therapeutic flora. While several key ethnobotanical species for cancer treatment will be foregrounded in this article, I recognize that an ethics of reciprocity relates to all therapeutic uses of medicinal plants. However, ethnobotanical species for cancer treatment offer salient examples of the need for a reciprocity ethics; conventional medical practices prioritize the alleviation of human suffering, but marginalize the importance of giving back to plants, of returning the favor, in the spirit of reciprocity. The conservation of medicinal plants in the wild ensures an ongoing reservoir of therapeutic plant compounds in the future. However, while we consume ethnobotanical plants and contribute to (or subtract from) the viability of their habitats, what do we return to the plants from which the medicines have been derived? In contrast to a utilitarian ethics of medicinal plants, the value of reciprocity foregrounds appropriate and sustained exchanges between people and flora that are not based on use-value or virtue-theoretics alone. Leslie Francis defines reciprocity as "the idea of actions-in-return that are not founded in voluntary agreements or contracts" and "doing one's part to produce a common good when-especially because-others are doing theirs [italics added]" [5]. A posthumanist approach to reciprocity recognizes that the term "others" intrinsically includes non-human or "more-than-human" species of flora, fauna, and fungi, not merely humans interacting with other humans. Moreover, a "common good" is also an ecological good, for the benefit of people, plants, and other beings, involving, among other things, the cycle of respiring together.

The taking from the plant world should involve a cycle of giving back to medicinal species that is not narrowly based in the human attainment of personal health or community well-being. Central to a 
reciprocity ethics is the understanding, to quote ethicist Francis again, that non-human "others are doing theirs",- - that medicinal plants have been offering physically, mentally, and spiritually therapeutic means to humanity (and have been doing so for thousands of years, as indicated by ethnobotanical evidence presented later); and that humanity should do its part, continue to do its part, or invent new ways of reciprocating with plants that ensure the well-being of both-for the intrinsic right-to-exist of both. In Reciprocity, originally published in 1986, the American philosopher Lawrence Becker characterizes the virtue of reciprocity as follows: "We ought to be disposed, as a matter of moral obligation, to return good in proportion to the good we receive, and to make reparation for the harm we have done." [6]. He goes on to classify reciprocity as a "deontic virtue", or a virtue of obligation based on three premises: "We owe a return for all of the good we receive, not merely the good we accept"; "the obligations of reciprocity come from the justifiability of being disposed to make reciprocation obligatory; [italics in original]" and "the sense of obligation here ought to appear to us, at least in many cases, only in retrospect”. While I accept Becker's first and second premises (returning for good received and being disposed toward reciprocity), I refute a deontic or virtue-theoretic approach over a prudential or act-morality approach. The sense of obligation should and must appear to us not only in retrospect but as a matter of forward-thinking. Reciprocity should and must become part of the moral fabric of our dealings with plants, as part of the foundation of ethnopharmaceutical ventures and conservation initiatives. The urgency of plant conservation necessitates an act-morality approach, a proactive position of considering the welfare of plants long before impacts have been made to them (as subjects-of-a-life) and to their habitats (as communities of abiotic and biotic things). I will enunciate this position in terms of the difference between "should" and "must".

\section{Traditional Ethnobotanical Treatments for Cancer: Global Contexts for Reciprocity}

As the world population undergoes the transition to the low mortality and low fertility patterns of industrialized nations, the global incidence of degenerative disease continues to increase. Among these, cancer is especially virulent. In 2012, there were approximately 14.1 million cases of cancer globally (up 225\% since 1997), with 7.4 million men and 6.7 women diagnosed. These statistics are expected to almost double by 2035, to 24 million confirmed cases of cancer [7]. In reaction to the increasing global frequency of cancer, a considerable amount of research has been invested in the identification of anti-cancer agents in traditional botanicals. Health research organizations, such as the National Cancer Institute (NCI), have examined the anti-cancer activity of traditional plant medicines as part of a global push to address the pandemic, which threatens people in developing and developed nations alike [8]. The ethno-medical systems of Native America, Africa, India, and China provide epidemiological leads to plants actually or possibly beneficial in treating cancer, either alone or in combination with other therapies. The value of reciprocity vis-à-vis these species and others should and must be developed as an integral aspect of future complementary health systems that involve plant medicines. By including "should" (suggestive) and "must" (imperative), I emphasize that our moral obligations to plants are both deontological (we must for the survival of the community) and prudential (we should for the benefit of ourselves).

Two themes are evident in the literature of ethnobotanical cancer remedies [9]. The first relates to the identification of plants that have been used traditionally to heal cancer and the relatively direct 
transmission of this knowledge to the dominant, or allopathic, medical paradigm. However, there usually is no strong correspondence between traditional uses of botanical medicines and their applications in allopathic paradigms. Factors such as exposure and predisposition to disease, traditional causes and concepts of disease, introduction of allopathic disease concepts and life expectancies underlie this lack of correspondence. In general indigenous terms for "cancer" comprise a variety of conditions including swelling, pain and malignancies, as the Navajo example will show later in this article. The second involves the annexation of botanical remedies, not traditionally known for the treatment of cancer, after the often-inadvertent recognition of potential anti-cancer compounds within the plants. In describing herbs used in cancer therapies, this article considers the interrelationships between these themes. In addition to outlining some of the major ethnobotanical remedies for cancer alongside a call for an ethics of reciprocity, this article also touches on causal (or etiological) reasoning, particularly the differences (and similarities) between traditional and Anglo-American rationalizations of cancer. The causal agents commonly attributed to cancer in the allopathic paradigm - preservatives, x-rays, radiation, smoking, and sedentary lifestyles - are more-or-less absent from traditional cultures (at least at the time of colonial contact), leading to the issue of differential etiologies and cultural perceptions of disease. For instance, certain food preservatives now banned or no longer widely consumed in some countries have been demonstrated (albeit tentatively) to underlie cancer. This causal relationship is evident in the example of the correlation between stomach cancer and the use of smoke and salt as preservatives [10].

Hence, the broader ethnobotanical and etiological questions briefly addressed here include, what is "cancer" in the traditional knowledge systems of some indigenous cultures; and what causes it? How do traditional perspectives of cancer influence the prescription or administration of ethnobotanical remedies? How can the ethics of reciprocity that I advocate enhance the efficacy of ethnobotanical species, while at the same time acknowledging the intrinsic right-to-exist of the plant and the imperative to "return good in proportion to the good we receive" from the botanical world? The next section explores the latter question in terms of environmental ethics.

\section{Plants as Subjects-of-a-Life: Individualistic, Holistic, and Gaian Approaches}

In order to develop a reciprocity ethics, I first will discuss the criticism that certain modes of environmental ethics privilege single organisms or species of organism - including human beings and ethnobotanical plants. Indeed, the reciprocity ethics I am calling for tends to focus on giving back to individual medicinal species, such as ginseng and devil's club. Is an individually-based ecological ethic really environmental, sustainable, or ethical at all? This provocation brings into focus the ideological rift between holistic and individualistic models that is evident in the literature. On one side, individualists aver that the principle of "subjects-of-a-life" [11] ethically distinguishes living beings (insects, bacteria, plants) from non-living things (rocks, soil, detritus) that are not rights-possessors. The ethical line drawn between species can create a hierarchy of environmental values in which ginseng and devil's club are privileged over the abiotic environment of which they are part. The positions of Peter Singer and Tom Regan, for example, express a concern for the welfare of individual ecosystem members, with particular attention paid to large, charismatic, sentient, and ostensibly intelligent mammals (and I would argue charismatic flora such as old-growth trees). In contrast, the 
holistic environmental paradigm, based in Aldo Leopold's land ethic, asserts an inherent relationship between the rights of the "land" (collectively including biological processes involving soils, plants, and animals) and the welfare of individual beings. In Leopold's model, the individual freedoms of subjects-of-a-life can sub-serve the rights of the ecosystem, especially when community interests are at stake. In other words, Leopold's model is a community-based environmental ethics in which land is conceived of as a society of beings and non-living things.

However, I suggest that the ethical structure underlying the holism of Leopold and also of the philosopher J. Baird Callicott-the correlative relationship between individual rights and the "integrity, stability, and beauty of the biotic community" [12]—is not entirely at odds with individualist models. Callicott builds on Leopold's holistic precepts, arguing that the land ethic is "self-consistently both [...] deontological [and] prudential" [13]; in other words, the reciprocal relationship between the natural world and the human community (indeed sustained by a land ethic) can ensure the welfare of both. In this context, the term "deontological" refers to human obligations, rules, and duties to the natural world; and is closely associated with virtue ethics and "doing one's part". "Prudential" refers to the good of the individual or the subject acting on behalf of itself. However, Leopold and Callicott equally fall short of articulating reciprocity as an environmental value, although the ethical tenet is implicit in their models, particularly Callicott's. As a counter-example to notions of reciprocity in holistic environmental ethics, the Gaia theory contends that the intrinsically self-regulating processes of the Earth - its organismic qualities - could give rise to new ecosystems, not necessarily including human societies, in response to the disturbance of the biosphere by climate change and other potentially catastrophic ecological issues [14]. By theorizing the homeostatic self-regulation of the Earth, Gaian theory seems to abnegate the place of environmental ethics of both kinds (holistic and individualistic) by ruling out the possibility of reciprocity (or mutual benefit) between the land and individual beings or species of beings, as discussed later in this article.

In contrast to Gaian theory, Leopold's land ethic has the potential to encompass reciprocity as an act-morality principle. Rather than the magnum opus of "environmental fascism" [15], the land ethic appeals to individual self-realization through reciprocal, dialogic engagement with an ecologically functional and intact community of beings and natural things. Therefore, healing plants are subjects-of-a-life as well as members of ecological (and social, cultural, economic, medicinal) communities, comprising human and non-human beings. The more that environmental ethical structures can avoid hierarchies and taxonomies, the more that true ecological justice can be realized. This is not merely blue-sky ideation. Our moral obligations to plants are both deontological (we must for the benefit of the community) and prudential (we should for the benefit of ourselves). It is only in reference to a land-as-community model (in Callicott's sense, building on Leopold's) that an ethics of reciprocity can be viable because reciprocal exchanges must be inclusive, thus involving subjects-of-a-life not traditionally encompassed within eco-ethical frameworks. These subjects include plants and, more precisely for this discussion, medicinal herbs, such as poke, jimson and devil's club of indigenous North American traditions, discussed in the next section. In summary, the position I am arguing for recognizes plants as subjects-of-a-life (extending Singer and Regan's work on animals) as well as plants as members of land-as-community (reflecting Leopold) while rejecting an ecological ethics based in Gaian theory. The subject-of-a-life is a priori a subject of an ecological community. 


\section{Poke, Jimson, and Devil's Club: Traditional Native North American Cancer Botanicals}

Indigenous North American nosology (disease classification) indicates the prevalence of rheumatism and arthritis, dysentery and other digestive disorders, intestinal worms, and eye disorders in Native American populations at the time of European contact. Modern diseases, such as cancer, heart disease, and arteriosclerosis, however, were uncommon [16]. Nonetheless, traditional ethnobotanical treatments for cancers and tumors existed and have been documented, as indicated by the following examples of poke, jimson weed, and devil's club.

American pokeweed (Phytolacca americana L.) is a pungent perennial herb of the family Phytolaccaceae, and is native to North America in dry fields, hillsides, and along roads. Its many folk names include Virginia poke, American nightshade, cancer jalap, coakum, garget, pigeon berry, pokebush, pokeberry, pokeroot, poke sallet, inkberry, ombu, redweed, and scoke. Indigenous North Americans used poke roots and berries medicinally. The large, mature root can be easily broken and sliced. A thin, brownish bark covering the fleshy and fibrous root tissue can be readily peeled. Dark purple, globular berries ripen in late summer and autumn in the Northern hemisphere. Although poke has a long history of efficacy in numerous indigenous North American medical systems, its toxicity in large amounts should caution potential modern users or experimenters [17]. For example, in traditional Cherokee medicine, an infusion of poke berries was taken for arthritis and rheumatism [18], whereas for the Delaware people, roots were used for glandular swellings and chronic sores, and to purify the blood [19]. In nineteenth-century North America, poke poisonings were documented, particularly cases involving the misapplication of the tincture as an anti-rheumatic and from the mistaken ingestion of the toxic berries. However, a tincture of the fresh root harvested in winter and a tincture of the ripe berries have been shown to be potentially helpful in the treatment of different cancers. Anecdotal evidence corroborates the efficacy of poke root, and indicates that Native Americans used the powdered root as a poultice for "cancerous ulcers" ([17], p. 351). Modern herbalism draws from the traditional usage of pokeweed root, ground fine, and applied as a poultice, most notably for the treatment of breast cancer [20]. Grated pokeroot can be applied to the breasts to treat inflammation and rashes. Moreover, research has shown that pokeweed antiviral protein (PAP) has antitumor properties in laboratory studies. Other studies have demonstrated that PAP can be used to treat advanced osteosarcomas and soft tissue sarcomas when combined with immunotherapy drugs [21]. A recent study (2014) indicates that alcoholic extracts of pokeweed change the expression of genes associated with colon cancer, potentially enhancing treatment [22].

Jimsonweed (Datura stramonium), or datura, is a species within a small genus of 12 species of shrubs or annual or perennial herbs, belonging to the nightshade family, Solanaceae. Jimsonweed is native to North America, an annual, over four feet tall when mature, with ovate, unevenly-toothed, glabrous, and pungent leaves; white or purplish funnel-form flowers; and a hard, barbed, multi-seeded capsule. Its numerous and often suggestive common names include thorn apple, green dragon, hell's bells, devil's trumpet, devil's weed, tolguacha, Jamestown weed, stinkweed, locoweed, prickly burr, devil's cucumber, and sacred datura. The name "jimsonweed" is a corruption of "Jamestown weed", supposedly derived from an incident during Bacon's Rebellion, an armed uprising of Virginia settlers in 1676. While jimsonweed is used as a medicine in Asia, where it was introduced, other datura species are native to the Old World. Although almost every part of the plant possesses medicinal 
properties, the most regularly used are the leaves and seeds. In large amounts, jimson weed is an energetic narcotic poison and is seldom prescribed by contemporary herbalists, or is used with extreme care in low doses ([20], p. 166).

Despite its dangers, jimsonweed has a wide range of traditional uses, in North America and Asia in particular. The smoke from the burning leaf is inhaled for bronchitis and asthma. The juice of the berries can be applied for dandruff and scalp disorders. Seeds and leaves are known to possess sedative properties and, thus, have been used to treat hysteria, psychosis, and insomnia. The compounds scopolamine, hyoscyamine, and atropine have psychotropic effects, underlying the use of jimsonweed for hallucinatory purposes in some traditions [23]. The Lumbee Indians of the Mississippi River report jimson weed as an external application for cancer, presumably as a poultice of the ground root or berries [24]. Moreover, anecdotal accounts confirm the application of seeds and extracts (tinctures of the root, for example) for a variety of acute afflictions, including "ulcerous affections and cancer" ([16], p. 327). Alkaloids, tannins, carbohydrates, and proteins in jimson are being screened by medical researchers as beneficial compounds in cancer treatment. The protein Datura Stramonium Agglutinin (DSA) has been isolated from jimson weed as a possible treatment for malignant gliomas of the brain [25]. Japanese scientists found that DSA entirely impeded the growth of cancer cells in a laboratory. When DSA was applied, the cells differentiated and lost their malignant properties. In this study, DSA was shown to induce the differentiation of glioma (tumor) cells, potentially offering a therapy for treating certain forms of cancer without the side effects of chemotherapy [26].

The last ethnobotanical example from the indigenous North American tradition briefly presented in this section is devil's club (Oplopanax horridus (Sm.) Miq.), a member of the Araliaceae family. Related to ginseng, devil's club possesses general tonic, or adaptogenic, properties. Its other common name is devil's walking stick. A widespread species in north-west British Columbia, devil's club is a deciduous shrub with a sprawling habit, three to 15 feet high, and grows in damp evergreen and mixed forests. Native American communities have long known devil's club to control diabetes [27]. The Gitksan (or Gitxsan) of British Columbia gather the leafless prickly stems and usually scrape off the inner cambium of the stems after senescence or when the plant is dormant. The inner bark of devil's club is applied dried or fresh for cancer, especially gynecologic, and for stomach ulcers [28]. In addition to its use in Gitksan culture, devil's club has been gathered as a cancer treatment in the Tlingit and Tsimshian cultures of north-west British Columbia ([28], p. 20). Recent medical research indicates that devil's club inhibits the growth of several forms of cancer. A study found an extract from the plant (OhE) effective for alleviating human colorectal cancer. OhE has also been shown viable as an ovarian and breast cancer therapy [29].

\section{Land Ethic as Framework for Reciprocity: Deontological and Prudential Regard for Plants}

The reciprocity framework that I am proposing, vis-a-vis medicinal plants, such as poke, jimson weed, and devil's club, should be developed in relation to a holistic environmental ethics that is both deontological (the good of the commons) and prudential (the good of the self), to again borrow $\mathrm{J}$. Baird Callicott's terms. The land ethic, formulated by the ecologically-versed and poetically-aware Aldo Leopold, certainly extends beyond him, past the Dust Bowl days of the American 1930s, and connects to the extant traditions of indigenous North American peoples, such as the Gitksan and 
Algonquian, who have developed complex traditions of giving back to the natural world in exchange for taking from ([13], p. 127). Indeed, indigenous models of reciprocity would have influenced Leopold's vision of cooperation and interdependence between human individuals and the land as a community of beings. The sustainability of traditional cultures across the world and over the millennia (for example, the 50,000-year cultural traditions of the Nyoongar of South-Western Australia) is a compelling indication of reciprocity between human communities and their local ecosystems. Exchange is prudential and intrinsic to the long-term welfare of cultures and beings [30]. However, it should be noted that longevity does not always correspond to ecological reciprocity. For example, environmental and cultural influences might maintain low human populations in which anthropogenic impacts are negligible, despite the intensity of activities by individuals or groups. Leopold reflects an appreciation of these traditions in his writing (although his Darwinian side shows through), characterizing an ecological ethic as "a limitation on freedom of action in the struggle for existence [italics added]" ([12], p. 95). In particular, he extends the reach of ethical concern to the land by thinking across the terms "politics and economies" (and thus about human social communities) and "symbioses" (and thus about ecocultural reciprocity) to illuminate the premise of interspecies relations linking both: "Politics and economics are advanced symbioses" ([12], p. 96). In Leopold's view, extending the logos of human ethics, the land ethic, to some degree, attempts to constrain the behavior of individuals in order to limit "free-for-all competition" ([12], p. 96). In other words, humans would not wantonly destroy human life; why should we cut down tracts of forest, drain wetlands areas, and exploit ethnobotanical plants through overharvesting, with no concern for the plants themselves or for the future of humanity's medicine?

However, the subjugation of individual rights to ecological oligarchy is not the core of Leopold's argument, though it might appear so on superficial reading. Instead, Leopold contends that, in order to benefit individuals, a community ethic should advocate land protection, which will return good to the individual in shared ways (for example, through the provision of clean air, food, and water, as well as spiritual rejuvenation in unspoiled places). In the land-as-community model, nature has both instrumental and intrinsic value; the former cannot be divorced from the latter, and both confer mutual advantage. Leopold alludes to the tacit effects of the land ethic on the individual: "An ethic may be regarded as a mode of guidance for meeting ecological situations so new or intricate, or involving such deferred reactions, that the path of social expediency is not discernible to the average individual." ([12], p. 96). The principle of "deferred reaction" is intrinsic to Leopold's thesis. Yet I suggest that this protracted effect, whereby the advantages to human communities are not immediately apparent, underlies the dichotomy between individualistic and holistic environmental ethics. In other words, the current of ethical concern for the community need not drive the individual to thirst, nor would Leopold have it this way. The land ethic is not a misanthropic position. Instead, it suggests that the community affects what is determined to be advantageous to individuals, and that which is suitable for the long-term welfare of ecological societies, including people and plants. As part of this reflexivity between the community and the individual, an ethics of reciprocity is intrinsic and signifies that all are doing their parts. Medicinal plants provide therapeutic compounds and spiritual sustenance (especially in the case of plants such as sacred datura) and human beings return the materials and modes of regard necessary for the long-term well-being of the plants (as subjects-of-a-life) and their habitats. 


\section{Psorospermum, Casava, and Periwinkle: Treating Cancer in Traditional African Ethnobotany}

In the previous section, I suggested that reciprocity is complementary (and arguably essential) to Leopold's land ethic; and that ecological ethicists ought to consider the moral implications of overusing, exploiting, commodifying, or driving to extinction plants used for human health and healing. This section goes on to detail other plants of relevance to the treatment of cancer, both historically and in contemporary allopathic contexts. Numerous plants used in African traditional medicine have been investigated for their cytotoxic (toxic to cells in higher doses but possibly therapeutic in lower doses) and antineoplastic (acting to prevent or inhibit neoplasms or tumors) properties. The three examples that follow-Psorospermum febrifugum Spach, Maprounea africana Müll.Arg., and Catharanthus roseus (L.) G.Don-will provide some indications of the potential of African plants to supply anticancer treatments in a world increasingly affected by cancers of different types and in a world in which wild plants are ever more threatened. However, I emphasize that the following three plants are not only the materials (chemicals, compounds, agents, substances) used for human health, but are first and foremost subjects-of-a-life in themselves, beyond their utilitarian applications and potentialities. Hence, the fields of medical herbalism and ethnobotany need to think beyond the use-value of plants and toward the subjectivities of the species involved, that is, toward plants as subjects-of-a-life with specific rights to exist in their original habitats.

Traditional African healers employ Psorospermum febrifugum, a bush found over wide areas of central and eastern Africa, including Senegal, South Sudan, Ethiopia, Mozambique, Zimbabwe, and Angola, to reduce fevers, as the species name indicates (febri-for fever). Psorospermum is in the Clusiaceae (or Guttiferae) family, consisting of 37 genera and over 1600 species distributed mainly in tropical areas. While investigating the antipyretic properties of the herb, researchers also identified anticancer compounds. Through an in vitro bioassay, scientists isolated from the roots of Psorospermum an antitumor and antiviral form of the compound xanthone called "psorospermin", which is active in controlling mammary and colon tumors. Another compound called an "anthrone" has been demonstrated in mice to possess in vivo activity against P-388 leukemia [31]. Moreover, Psorospermum extracts were found to be effective against A2780cis ovary cells, a malignant cell type that is resistant to the anticancer drug cisplatin. Omodin is an antitumor compound identified in the species as valuable for treating lung, prostate, ovarian, colon and hepatic cancers [32].

Magic nut, redskin bush or mburabu (Maprounea africana) has been used in traditional Eastern African cultures as a purgative and to cure syphilis. Although sometimes referred to as tree cassava, M. africana should not be confused with Manihot glaziovii, an Amazonian species introduced to Africa and also known by this common name. Magic nut is a deciduous shrub or small tree with hanging branches and reddish-brown twigs and reddish-yellow flowers in heads. The species occurs in Benin, Tanzania, Angola, Namibia, Botswana, Zimbabwe, and Mozambique. Its bark is taken as a purgative in low doses, with larger amounts being highly toxic and potentially fatal. A decoction of the root is consumed traditionally to alleviate syphilis, venereal diseases, leprosy, and dysentery. Preparations of the roots, bark, and leaves are employed in Gabon as a diuretic. In Congo, stems and leaves are chewed for constipation, intestinal worms, and irregular menstruation [33]. Alcoholic extracts of the dried roots exhibit activity against p-388 leukemia in mice. Further research has led to 
the identification of a number of pentacyclic triterpenes, one of which is highly active in the p-388 in vivo test ([31], p. 121).

Indigenous people in Madagascar use rosy periwinkle (Catharanthus roseus) as a treatment for insect stings, eye infections, toothaches, malaria, diabetes, and cancer. The species is also known as vinca, Cape periwinkle, and old maid; and is endemic to Madagascar although it is found elsewhere, including Jamaica. Periwinkle is an herbaceous plant with oblong leaves and white to dark pink flowers with red centers. In 1958, Gordon Svoboda screened a periwinkle extract, later identifying over 70 alkaloids in the plant. In fact, specimens of Catharanthus roseus were collected in Jamaica for use in diabetes trials, but the results were inconclusive. Attempts to verify the folkloric use of periwinkle as a diabetes treatment later led serendipitously to the identification of two alkaloids applied in the clinical treatment of cancer [34]. These alkaloids, vincristine and vinblastine, are now common around the world in treating pediatric leukemia and Hodgkin's disease ([8], p. 33). The alkaloids inhibit the division of cells in lymphomas, leukemias, and tumors. While these chemotherapy drugs are now well established as important treatments for various types of cancer, none of the benefits of over 50 years of commercialization have been shared with indigenous people of Madagascar while periwinkle itself becomes gradually more endangered in its native habitat [35]. Although its status in the wild is compromised, because of the impacts of agricultural practices, the species is extensively cultivated outside of Madagascar. This brief example demonstrates a highly utilitarian, capitalistic, and exploitative approach to ethnobotanical species in which reciprocity is not figured into modes of exchange between the plant, local indigenous people, and the pharmaceutical industry.

\section{Ethics as Community Instinct: Love and Respect for Medicinal Plants}

Concepts of reciprocity between land and organism, between community and member, between free energy and individual form, are nascent within Leopold's land ethic. Regarding his marginalization of the role of the individual, J. Baird Callicott in "The Conceptual Foundations of the Land Ethic" comments that most philosophers have regarded the land ethic "with horror because of its emphasis on the good of the community and its de-emphasis on the welfare of individual members of the community" ([13], p. 125). I suggest that part of mainstream philosophy's "horror" is due to the non-dualistic nature of reciprocal engagement with the land and other living beings, in which the I-thou distinction dissolves, and the highly individuated subject becomes an unstable ontological state. In a paradigm of reciprocity, self-interests cannot be achieved through self-dialogue, or through a form of environmentally dangerous solipsism. For Leopold, concepts of community and ecosystem embed the individual. For Callicott, the ecosystem provides the context of individual assertions, but, more specifically, genetic predeterminations underlie our feelings, instincts, and capacities - for "love, sympathy, respect" ([13], p. 131) — nurturing the developmental processes and maintaining the community as the site of all ecosocial interactions. Hence, for Callicott, love and respect for the natural world are as important to an ethics of reciprocity as they are to civil society.

Extending Leopold's notion of deferred social expediency to the evolutionary origin of community ethics, Callicott concludes, as stated previously in this article, that the land ethic is both deontological and prudential. As "a kind of community instinct in-the-making" ([12], p. 203), ethics is a deontological appeal to community demands through values of duty, self-sacrifice, love, and respect 
for non-human beings, including ethnobotanical species, such as periwinkle and tree cassava, and their broader habitats. Genetically influenced in Callicott's view, the frameworks of environmental ethics ensure community good by constraining purely personal gain (read: the small percentage of mining magnate billionaires in Australia) where the good of the whole becomes, reciprocally, the good of the individual (read: to live a life of quality, unrelated to the greedy accumulation of capital). However, the land ethic is ultimately also prudential because ethical treatment of land returns good to individuals, particularly in the form of ecological good (clean air, food, water). These dynamics between prudential concern and deontological regard for the environment are best summarized in Callicott's statement that " "there is no way for land to survive the impact of mechanized man [sic]', nor, therefore, for mechanized man [sic] to survive his [sic] own impact upon the land" ([13], p. 132). In the context of mechanized allopathic health care that looks to integrate (and, in many instances, exploit) ethnobotanical traditions, such as those previously described, survival in all senses depends on land, despite the carrying out of laboratory investigations in sterile spaces and the illusion of detachment from ecological exigencies during experimental processes. Love, respect, and reciprocity need to underlie all interactions with ethnobotanical species and with the indigenous people who have safeguarded them for thousands of years. This returns good to the plants in their environments commensurate to the good we receive from them in the form of medicinal compounds, community well-being and, perhaps most importantly, the realization that we are not alone on this planet, that we are always part of ecocultural communities.

\section{Ashvaganda, Ginseng, Reishi, and Licorice: Ayurvedic and Chinese Medicinal Plants}

Ayurvedic and ancient Chinese medical systems have well-established traditions of using plants as therapeutic agents for a variety of ailments. Ayurvedic treatments for cancer exhibit a constitutional basis, in which a unique remedy is determined according to the alignment of the patient or condition to one dosha or a combination of doshas: vata (air), kapha (earth), and pitta (fire). Robert E. Svoboda's book Ayurveda: Life, Health and Longevity describes the case of Dr Agate, a professor in an Ayurvedic college, who was diagnosed with advanced stage acute myeloblastic leukemia (AML) and given no longer than one year to live [36]. Ignoring blood reports, bone-marrow tests, and the overall allopathic diagnosis, he focused on Avurvedic therapies, in which the intense pain in his bones and joints was attributed to the vata dosha and wind invasion. Agate carefully followed a regime of herbs prescribed by a consulting Ayurvedic physician. The treatment took the form of a powder containing ashvaganda (Withania somnifera L. Dunal), sariva (Indian sarsparilla, Hemidesmus indica $\mathrm{R}$. Br.), and amalaki (Indian gooseberry, Emblica officianalis Gaertn.). The blast cells in Agate's blood began to return to normal after about six months and eventually he could resume his teaching duties.

Of the three herbs used by Agate, ashvaganda exhibits scientifically documented anticancer properties ([36], pp. 298-301). Regarded as the primary Ayurvedic strengthening tonic, or an adaptogen like ginseng and Devil's club, ashvaganda is a perennial herb that grows to a height of five feet with a width of about three feet. The stem is green and erect; the leaves are ovate, green, and alternate; the flowers are small, greenish white with a white stigma; and the red berries are encased in a papery sheath. With sedative and narcotic properties, ashvaganda is a widely used herb in Ayurvedic medicine. It has documented antitumor activity, largely attributed to the major chemical component, 
withanolides (steroidal lactones), including somiferin and withaferin A [37]. Ashvaganda extracts have been demonstrated to increase platelet and red and white blood cell counts during cancer chemotherapy treatment with cyclophosphamide. Moreover, animal studies in India conclude that ashvaganda sensitizes cancer cells to radiation therapy, making treatments approximately fifty percent more efficacious. Studies have shown that ashvaganda facilitates the regression of cancerous tumors [38].

As in Ayurveda, the traditional Chinese botanical treatment for cancer focuses on tonifying the whole body, not just the afflicted organ or system. Only in the last few decades has the efficacy of various Chinese herbs been subjected to allopathic methods of scrutiny, such as screening tests. In particular, Chinese herbal medicine exemplifies the role of traditional botanical tonics in the contemporary treatment of cancer. Ginseng (Panax ginseng Meyer) has been central to Chinese medicine for over two thousand years as an aphrodisiac, painkiller, and general stimulant, although American ginseng (Panax quinquefolius L.) is even more highly valued. P. ginseng is a low-growing perennial plant, native to regions of China, North Korea, and Siberia. In the autumn, ginseng root is dug, washed, steamed, and dried for use. A study in South Korea observed that individuals who habitually consume ginseng have a sixty percent lower incidence of death from cancer, especially of the lungs and stomach. Additionally, research in China found that when ginseng therapy was combined with traditional radiation and chemotherapy for small cell lung cancer, the patient's life span increased by three to seventeen years. Moreover, polyacetylinic alcohol in ginseng impedes tumor cell reproduction and augments the effectiveness of the drug mitomycin in stomach cancer therapy. A study of almost 2000 individuals concluded that regular ginseng use reduces the likelihood of developing many forms of cancer ([38], p. 74).

Reishi (Ganoderma lucidum (Fr.) P. Karst) is regarded as an "elixir of life" in Chinese medicine and is increasingly known around the world as a potent tonic for energy, disease resistance, and longevity. Although over ninety-nine percent of all wild reishi mushrooms are found growing on old plum trees, fewer than 10 mushrooms will be found on 100,000 trees, lending the reishi its common name "phantom mushroom." Some of its other vernacular names are lingzhi and king of herbs. Reishi has numerous therapeutic applications, for example, anticancer, immunoregulatory, antioxidant, liver-protecting, hypoglycemic, antibacterial, antiviral, antifungal, and blood cholesterol lowering effects. Reishi activates the body's production of interleukin-2, which protects against several kinds of cancer, and contains ganoderic acids, which act against liver cancer. Reishi counteracts the suppression of red and white blood cells that can result from cyclophosmamide treatment by stimulating the production of bone marrow protein ([38], p. 116). Another study of reishi concluded that the fungus suppresses the adhesion and migration of invasive prostate and breast cancer cells, suggesting its usefulness in reducing tumor development of these kinds. The anticancer properties exhibited by Ganoderma underscore its potential as a dietary supplement in conjunction with other alternative therapies for cancer treatment [39].

The final plant discussed in this section, licorice (Glycyrrhiza glabra L.), has been used for over 3000 years in traditional Chinese medicine as a tonic to rejuvenate the heart and spleen, and as a treatment for ulcers, cold symptoms, and skin disorders. Also known as sweet root, licorice contains sugar-like compounds and has been used for a range of ailments, particularly as a demulcent and expectorant. Native to parts of Europe and Asia, licorice is a woody-stemmed perennial that attains 
a height of six feet, bearing clusters of creamy white flowers. In the autumn, roots of three- to four-year-old plants are dug up. Licorice protects the body against a range of carcinogenic compounds, including chemotherapy toxins. Glycyrrhiza prevents the formation of skin tumors caused by noxious chemicals. Additionally, licorice hinders the cancer-causing effects of pollutants, such as benzopyrenes, and a chemical called aflatoxin that results from improperly stored food grains. Licorice also defends the body against some arsenic compounds, urethane, caffeine, and nicotine ([38], p. 91). Recent research indicates that licorice slows the growth of skin cancer cells by blocking the proteins required for the development of melanomas. Another chemical in licorice, isoangustone A, has properties similar to glycrrhizin but without the associated side effects of arrhythmia, high blood pressure, and muscle weakness [40].

\section{Gaia Theory and an Ethics of Reciprocity: Can There Be Agreement?}

The principles underlying Leopold's land ethic and the community ethics of Callicott imply the value of reciprocity between community and individual. Yet reciprocity as a principle in itself is not explicitly developed in their arguments. Making reciprocity explicit and providing a theoretical framework for doing so have been the focal points of this article. Despite the criticism that the land ethic marginalizes the individual for the welfare of the whole, the holistic environmental ethics of Leopold and Callicott, in fact, implicitly attend to the well-being of both the individual and the community - the organism and ecosystem. An individualism enhances the community (i.e., the land, habitat, biological system) while a collective focus strengthens the constituents (i.e., the subjects-of-a-life). This is the context for reciprocity-in which acts of contributing to and giving back (or doing one's part) can take place. The reciprocity ethics I am calling for is both species- and land-based.

In contrast to a land ethics, the Gaia hypothesis developed by Lovelock and Margulis theorizes the Earth as a homeostatic system that alters its ecological processes-soil and atmospheric composition, and floral and faunal make-up - in response to human interventions. In their view, homeostasis (involving broad scale temporal and geological phases) is a normative feature of the Earth's ontology. The planet regulates factors of climate and temperature in order to establish suitable conditions for community members - human and non-human, biotic and abiotic. Gaia theory calls attention to life facing decline in the event of a global equilibrium shift, triggered, for instance, by climate change. In this framework, planetary life systems, perpetually in flux and adapting to new conditions, are not contingent on conditions of reciprocal exchange over time. In fact, Lovelock considers ideas of planetary stewardship to be ridiculous and dangerous "hubris". Since we will never know enough about the complexities of microscopic life - in his view, the basis of the Earth's life systems - an ethical approach is a hands-off one that minimizes human involvement and, therefore, seems to abnegate ethical responsibility [41]. A Gaian perspective counters the position that human life and land-as-community are bound to reciprocal engagements. Humanity ultimately bears the consequences of ecological myopia and acts of reciprocity cannot turn the tide.

In another sense, the extreme holism of Gaian theory can lead us full circle to individualistic concerns. If the consequences of global climate change are definitive, then a course of action is to re-emphasize the place of the individual, in order to protect ourselves from radical ecological shift. 
This emphasis on the individual suggests that the community and its members are interdependent, as Leopold and Callicott would have it. In Gaian theory, ethical frameworks are constructions having no real bearing on the planet's well-being. If the planet's feedback mechanisms involve a constant state of flux over the millennia, how can we define or isolate a baseline state of ecological well-being from which ethics can proceed? How can we determine land health in the context of Gaian theory in which our limited human vantage point is a stark and isolated one within the expanse of the Earth's geological history? The breakdown of notions of reciprocity in light of Gaian theory is in contrast to the land ethic, where collective concerns of survival, autonomy, and self-realization play out. Gaian theory is at odds with the land ethic, although both are often erroneously subsumed within the heading "holistic ethics". Moreover, individualistic philosophies (in my view, not sufficiently articulated by ethicists such as Singer and Regan) and the land ethic (of Leopold and Callicott) are less in opposition than they appear, or at least should be regarded as less antagonistic if genuine practices of reciprocity are to be realized.

The holistic ethics of Leopold and Callicott — rather than Gaian theory-offer an amenable position from which to advance notions of reciprocity in relation to the land ethic and medicinal plants. When an ecosystem fails, so does human and botanical well-being alike. This exigency touches on the core of contemporary environmental problems: the disruption of the land community (through pollution, deforestation, loss of biodiversity) is intimately linked to the decline of the individual organism (through air quality depletion, disease, loss of hope). In other words, an ethics of reciprocity concerns the whole (i.e., earth, communities, systems) in dialogic exchange with the constituents (i.e., subjects-of-a-life). As Callicott argues, this position mediates prudential self-interest and deontological concern for community. In recognizing plants as subjects-of-a-life, we come to see them also as members of land-as-community. A reciprocity ethics is one that returns good to plants and their broader biocultural environments, despite Gaian contexts of climate change which can disempower such a position. My exploration of ethnobotanical treatments for cancer affirms the following point: the receiving of ethnobotanical good should be balanced by a giving back of good to the plants themselves, the environments in which they grow naturally, and the indigenous people whose cultural heritage involves medical knowledge of the species. It is not enough to privilege cultivating healing plants as a solution to their disappearance in the wild. As species decline, the ecocultural knowledge systems associated with them become at risk, as the next section goes on to explain through the example of the Navajo experience of cancer.

\section{Cancer, Camas, and Croton: Traditional Ecological Knowledge and Reciprocity with Plants}

Reciprocity with the botanical world also entails reciprocity with indigenous peoples who have maintained traditions of healing with plants for centuries and whose ecological knowledge often informs (and is exploited by) medical science. Thus far in this article, traditional botanical healing agents for cancer have been examined in reference to some modern research that has either expanded on their traditional uses or disclosed previously unknown anticancer properties. However, the cause, meaning, and identity of cancer in traditional knowledge systems underpin the use of ethnobotanical curatives. An example of Navajo conceptualizations of cancer will provide some insight into cross-cultural etiology and nosology. For example, two patients in a study claim to have been 
definitively cured of cancer, one by traditional herbs and one by peyote (Lophophora williamsii (Lem. exSalm-Dyck) J.M. Coult). In the study, forty-three percent of traditional treatments used by Navajo cancer patients involved Navajo herbs administered in the Lifeway, Pus-eater, or peyote ceremonies. As indicated by the term "Pus-eater", Navajo thought conceptualizes cancer as a putrescent sore, rather than as a growth or tumor: "Negative, uncontrolled growth is a less culturally salient metaphor for Navajos than for ourselves. In Navajo thought, growth is inherently positive, whereas degeneration and decay are characteristically negative processes [...] To conceive of cancer as something that 'keeps on rotting' is more consistent with such a view, while our own conceptualization of 'unchecked growth' is consistent with our fear of nature (and society) out of control." [42]. Navajo etiology accordingly describes cancer by using a vocabulary of decay, rather than one of negative growth, as common to the allopathic perspective.

Instead of a basis in syndrome and symptom, the Navajo disease classification system centralizes etiology, or causation. In contrast to the causation cited by Anglo-American participants, Navajo patients ranked lightning as an important etiological category. To the Navajo, lightning is more than a cosmological and an environmental reality. It is a metaphorical fact of life: the category of lightning extends beyond the storm-related kind to include other forms of radiant energy. For example, radiation from a uranium mine and exposure to the flames and fumes of a welder's torch were cited by Navajo patients as likely causes of their illness. The study suggests that a physical or bodily cause (injury) ranks significantly alongside a spiritual or celestial cause (lightning). The Navajo conceptualization of cancer provides a brief insight cross-cultural etiology, but most importantly, the example underscores the capacity of traditional ethno-medical systems to encompass and adapt to modern disease classifications. Lightning is an archetypal form of radiation, but radiation is also a modern Navajo interpretation of the traditionally broad etiological category of shooting phenomena, including snakes and arrows ([42], p. 465).

For indigenous cultures such as the Navajo, an ethic of reciprocity is closely related to medicine and food. As such, notions of self-interest are not generally reflective of individual behaviors in which deontological concerns balance purely prudential ones. Historian Adam Sowards in his book United States West Coast: An Environmental History (2007) opens the chapter "Reciprocity and the Indigenous Landscape" with a scenario of a Native American woman of the Pacific Northwest using a digging tool to search for the blue flowers of camas (Camassia quamash (Pursh)) [43]. Also known as Indian hyacinth or wild hyacinth, camas species were important food sources for Native American peoples and early settlers. The bulbs were roasted or boiled, tasting like sweet potatoes, or pounded into flour and stored. In Sowards' anecdote, the woman and her companions prepare to dislodge the bulbs of the season's first camas from the earth. In return for the nutritious bulb, the women offer their tobacco and prayers, asking permission to harvest before proceeding to do so. They also returned the flowering stalk of the plant to the earth. Some of the camas were stored away for winter ceremonies. Others were boiled and mixed with a sweetener to prepare a cough medicine. This ritualized harvesting of a plant involves taking as a form of borrowing from and giving back to the earth.

A modern example of reciprocity as an ethic comes from Shaman Pharmaceuticals, a defunct company, later reincarnated as Napo Pharmaceuticals, that has bioprospected traditional knowledge from indigenous healers and herbalists to create FDA-approved ethno-pharmaceuticals. The company commits a percentage of its profits to the indigenous communities from whom they have acquired 
ethnobotanical intellectual property. Shaman also founded the Healing Forest Conservancy, a nonprofit organization aimed at compensating indigenous peoples by preserving cultural and biological heritage [44]. The drug crofelemer is derived from sangre de grado or sangre de drago (Croton lechleri), a tree native to northwestern South America that yields a red resin known as dragon's blood. The plant-derived drug regulates intestinal water and prevents dehydration, thus providing a treatment for AIDS- and HIV-related diarrhea. In January 2013, the FDA approved Shaman's crofelemer, under the trade name Fulyzaq, for this purpose. The drug was also approved for treating infectious diarrhea in children, a leading cause of childhood death in some countries. A different study investigated the use of $C$. lechleri in comparison with taxol and vinblastine to control melanoma cancer cells. Researchers found that the plant medicine inhibited cancer cell proliferation, thus supporting the traditional use of the sap as an anticancer agent [45].

An ethics of reciprocity contrasts starkly with practices of biopiracy, defined as forms of bioprospecting that involve exploitation of indigenous knowledge by commercial entities. Geographer Daniel Robinson regards biopiracy as "the appropriation of biological resources and associated knowledge, particularly from the most biodiverse developing countries and from farmers, indigenous peoples and local communities" [46]. Key accounts of biopiracy include Vandana Shiva's Biopiracy: The Plunder of Nature and Knowledge (1997) [47] and Darrell Posey's work in ethnobiology [48], both of which argue for ethical standards governing the commodification of traditional knowledge, including of medicinal plants. However, while critics of biopiracy advocate stronger rights for indigenous groups and the protection of the intellectual property related to their traditional ecological knowledge, an ethics of reciprocity with non-human species has not figured into their analyses. As such, conceptualizations of biopiracy are strongly human-centered, without the multispecies focus of posthumanist thinking.

In this section, we have seen both traditional and commodity-based examples of reciprocity, as well as the broad importance of giving back to plants and people for the good they provide. Indeed, the act of giving back to the vegetal world can take a multitude of forms, which need to be identified, conceptualized and designed according to the plant species, human communities, indigenous traditions and biological habitats involved. However, by committing to reciprocity ethics, researchers, activists and community members can ensure not only the longevity of plants species in their native habitats but their flourishing and well-being as subjects-of-a-life. An ethics of reciprocity can manifest as the intimate act of returning parts of the flower to the earth or the grander act of establishing ecological reserves to protect plant species and their wild habitats. Deciding which forms of reciprocity to put into practice depends on a range of factors (indigenous, cultural, social, ecological, botanical) that ensure the ethical purpose of these acts.

\section{Conclusions: Indigeneity and Ethnobotanical Reciprocity}

The previous section briefly addressed the question, "what is 'cancer' in traditional indigenous knowledge systems, and what causes it?" The Navajo conceptualization of cancer reflects a close association with the ecology of south-western North America. As a primary causal agent, lightning is a form of radiation, which is furthermore a shooting phenomenon. Arrows, lightning, and radiation figure into traditional Navajo cancer understandings in which modern causal agents (such as radiation) 
are integrated into an indigenous knowledge framework. The previous section also asked, "how does a traditional perspective of cancer influence the prescription or administration of botanical remedies?" A notable example from the Navajo study is the Pus-eater ceremony, and the herbal agents associated with it, for treating cancer as a condition of sores, pus, and decay. Moreover, in the traditional medical systems of China and India, the treatment of cancer involves treating the entire body, not solely the diseased organ. The efficacy of traditional tonics-Oplopanax horridus, Withania somnifera, Panax ginseng, and Ganoderma lucidum - in treating cancer suggests that health is a condition of the whole body, not only its parts. Whereas allopathy focuses a diagnosis on one organ or one bodily region, the ethnobotanical medicine of ancient China and India regards disease as an affliction of the entire organism, and thus prescribes tonics to build immune reserves and foster the body's systemic integrity.

The global prevalence of cancer indicates a basis in the byproducts of technological societies: "Cancer is evidently a much more important disease in modern America than it was in native America." [49]. By contrast, the majority of diseases and disorders of traditional cultures stemmed from nutritional deficiency, injury, overexertion, and exposure to climatic extremes. Plants such as Taxus traditionally were used for rheumatism, colds, and lung disease. However, with the isolation of paclitaxel (taxol) from the Pacific yew tree (Taxus brevifolia), the same species has yielded a useful cancer drug, as reported in the WHO Model Lists of Essential Medicines and confirmed by the National Cancer Institute ([49], p. 13). The Pacific Northwest Coast Tsimshian people have utilized Taxus brevifolia as a cancer treatment at the extreme north end of the range of the species. Although it is problematic to impose conventional medical ideas on traditional ethno-medical systems, the common factor of plants as sources of therapeutic agents brings both systems into dialogue. Ethnobotanists identify plants with anticancer properties by understanding traditional knowledge and searching for species that are known to be effective against conditions associated with cancer, such as inflammation. Plants used traditionally to treat "cancer" symptoms are identified and adopted by allopathic medicine after biochemical analysis, as the examples of crofelemer and taxol indicate. Moreover, as indicated by the use of African periwinkle as a leukemia treatment, the anticancer properties of a species are identified when researchers investigate seemingly unrelated potential applications of the plant in medicine.

However, as I have argued, the value of reciprocity is often left out of these ethno-medical processes where exchanges between plants, indigenous people, and the allopathic medical paradigm are focused on use-value: how effectively a species, such as dragon's blood, can be converted to an FDA-approved medicine or commodified through another means with no address to the plant as a subject-of-a-life. I refute Becker's purely virtue-theoretic approach to reciprocity ethics over an act-morality approach because ethnobotanical treatments for cancer are contingent on the well-being of plant lives in order to be effective agents for the well-being of humans. As habitat loss and climate change threaten vegetal and human lives alike, there is no place for a virtue-theoric approach to reciprocity. Researchers estimate that the loss of global vascular plant diversity between 1995 and 2050 will be 25 percent. The most impacted ecosystems will be tropical woodlands and forests, savannahs, and shrublands. During the 50-year period between 2000 and 2050, land use disruption will contribute more to species loss rates and patterns than climate change [50]. We cannot wait for "the sense of obligation [...] to appear to us [...] in retrospect," as Becker would have it. A sense of obligation to medicinal plants should appear to us as foresight, as thinking about our duties to the plant 
world as part of the fabric of our exchanges with them. An ethics of reciprocity that is both deontological and prudential, in Callicott's terms, regards the land as a community of beings, not the least of which are the plants that provide humanity with the medicines of the past and future. The multiple forms that reciprocal exchanges can take should be the subject of further philosophical and ethnobotanical questioning.

\section{Acknowledgments}

The author thanks the University of Lancaster (UK) and Edith Cowan University (Australia), especially the CREATEC research center in the Faculty of Education and Arts, for their support during this research.

\section{Conflicts of Interest}

The author declares no conflict of interest.

\section{References}

1. David Eisenberg, Roger Davis, Susan Ettner, Scott Appel, Sonja Wilkey, Maria Van Rompay, and Ronald Kessler. "Trends in Alternative Medicine Use in the United States, 1990-1997: Results of a Follow-up National Survey." The Journal of American Medical Association 280 (1998): 1569-75.

2. Hilary A. Tindle, Roger B. Davis, Russell S. Phillips, and David M. Eisenberg. "Trends in the Use of Complementary and Alternative Medicine by US Adults: 1997-2002." Alternative Therapies in Health and Medicine 11 (2005): 42-49.

3. Michael Murray. "Botanical Medicine: A Modern Perspective." In Textbook of Natural Medicine. Edited by Joseph Pizzorno and Michael Murray. St Louis: Churchill Livingstone, 2013, pp. 255-60.

4. Anna Waldstein. "How Can Ethnobotany Contribute to the History of Western Medicine? A Mesoamerican Answer." In Critical Approaches to the History of Western Herbal Medicine: From Classical Antiquity to the Early Modern Period. Edited by Susan Francia and Anne Stobart. London: Bloomsbury, 2014, pp. 271-88.

5. Leslie Francis. "Reciprocity and Environmental Obligations." Hofstra Law Review 37 (2009): 1007-14.

6. Lawrence Becker. Reciprocity. Oxon: Routledge and Kegan Paul Ltd., 2014, p. 3.

7. J. Ferlay, I. Soerjomataram, M. Ervik, R. Dikshit, S. Eser, C. Mathers, M. Rebelo, D.M. Parkin, D. Forman, and F. Bray. "GLOBOCAN 2012 v1.0, Cancer Incidence and Mortality Worldwide." IARC CancerBase, 2013. Available online: http://globocan.iarc.fr/Pages/fact_sheets_population. aspx (accessed on 23 October 2014).

8. Michael Balick, and Paul Cox. Plants, People, and Culture: The Science of Ethnobotany. New York: Scientific American Library, 1996.

9. Gary Martin. Ethnobotany: A Methods Manual. London: Earthscan, 2007. 
10. Elizabeth Fontham, and Su L. Joseph. "Prevention of Cancers of the Esophagus and Stomach." In Preventative Nutrition: The Comprehensive Guide for Health Professionals. Edited by Adrianne Bendich and Richard Deckelbaum. Totowa: Humana Press, 2005, pp. 25-54.

11. Tom Regan. "Animal Rights, Human Wrongs." In Environmental Philosophy: From Animal Rights to Radical Ecology. Edited by Michael Zimmerman and Callicott J. Baird. Englewood Cliffs: Prentice-Hall, 1993, pp. 33-48. (Originally published in 1980).

12. Aldo Leopold. "The Land Ethic." In Environmental Philosophy: From Animal Rights to Radical Ecology. Edited by Michael Zimmerman and J. Baird Callicott. Englewood Cliffs: Prentice-Hall, 1993, pp. 95-109. (Originally published in 1949).

13. Callicott J. Baird. "The Conceptual Foundations of the Land Ethic." In Environmental Philosophy: From Animal Rights to Radical Ecology. Edited by Michael Zimmerman and Callicott J. Baird. Englewood Cliffs: Prentice-Hall, 1993, pp. 110-34.

14. Stephen Henry Schneider. Scientists Debate Gaia: The Next Century. Edited by Stephen Henry Schneider. Cambridge: MIT Press, 2004.

15. Tom Regan. The Case for Animal Rights. Berkeley: University of California Press, 1983, pp. 361-62.

16. Virgil Vogel. American Indian Medicine. Norman: University of Oklahoma Press, 1970, p. 161.

17. Alma Hutchens. Indian Herbalogy of North America. Boston: Shambhala Hutchens, 1991, pp. 223-24.

18. Paul Hamel, and Mary Chiltoskey. Cherokee Plants and Their Uses: A 400 Year History. Sylva: Herald Publishing Co., 1975.

19. Gladys Tantaquidgeon. Folk Medicine of the Delaware and Related Algonkian Indians. Harrisburg: Pennsylvania Historical and Museum Commission, 1972.

20. Dominion Herbal College. Chartered Herbalist Course Book Two. Burnaby: Dominion Herbal College, 1969, p. 13.

21. American Cancer Society. "Pokeweed." Available online: http://www.cancer.org/treatment/ treatmentsandsideeffects/complementaryandalternativemedicine/herbsvitaminsandminerals/ pokeweed (accessed on 5 September 2014).

22. L. Maness, I. Goktepe, H. Chen, M. Ahmedna, and S. Sang. "Impact of Phytolacca americana Extracts on Gene Expression of Colon Cancer Cells." Phytotherapy Research 28 (2014): 219-13.

23. Richard Evan Schultes, Albert Hoffman, and Christian Rätsch. Plants of the Gods: Their Sacred, Healing, and Hallucinogenic Powers. Rochester: Healing Arts Press, 2001.

24. Edward Croom. "Herbal Medicine among the Lumbee Indians." In Herbal and Magical Medicine. Edited by James Kirkland, Holly Mathews, Charles Sullivan and Karen Baldwin. Durham: Duke University Press, 1992, pp. 137-69.

25. Cancer Research UK. "DSA from Jimson Weed for Brain Tumours." Available online: http://www.cancerresearchuk.org/cancer-help/about-cancer/cancer-questions/dsa-from-jimsonweed-for-brain-tumours (accessed on 5 September 2014).

26. T. Sasaki, K. Yamazaki, T. Yamori, and T. Endo. "Inhibition of Proliferation and Induction of Differentiation of Glioma Cells with Datura Stramonium Agglutinin." British Journal of Cancer 87 (2002): 918-23. 
27. Donald Yance. Adaptogens in Medical Herbalism: Elite Herbs and Natural Compounds for Mastering Stress, Aging, and Chronic Disease. Rochester: Healing Arts Press, 2013.

28. Leslie Johnson Gottesfeld, and Beverley Anderson. "Gitksan Traditional Medicine: Herbs and Healing." Journal of Ethnobiology 8 (1988): 13-33.

29. Xiao-Li Li, Shi Sun, Guang-Jian Du, Lian-Wen Qi, Stainley Williams, Chong-Zhi Wang, and Chun-Su Yuan. "Effects of Oplopanax horridus on Human Colorectal Cancer Cells." Anticancer Research: International Journal of Cancer Research and Treatment 30 (2010): 295-302.

30. Deborah Bird Rose. Nourishing Terrains: Australian Aboriginal Views of Landscape and Wilderness. Canberra: Australian Heritage Commission, 1996.

31. Kurt Hostettmann, and Andrew Marston. "Plants Used in African Traditional Medicine." In Folk Medicine: The Art and Science. Edited by Richard Steiner. Washington: American Chemical Society, 1986, pp. 111-24.

32. Jean de Dieu Tamokou, Jean Rodolphe Chouna, Eva Fischer-Fodor, Gabriela Chereches, Otilia Barbos, Grigore Damian, Daniela Benedec, Mihaela Duma, Alango Pépin Nkeng Efouet, Hippolyte Kamdem Wabo, et al. "Anticancer and Antimicrobial Activities of Some Antioxidant-Rich Cameroonian Medicinal Plants." PLOS One 8 (2013): 1-14.

33. Gaby Schmelzer. Plant Resources of Tropical Africa: Medicinal Plants. Edited by Gaby Schmelzer. Wageningen: PROTA Foundation and Backhuys Publishers, 2008, p. 376.

34. Robert L. Noble. "The Discovery of the Vinca Alkaloids: Chemotherapeutic Agents against Cancer." Biochemistry and Cell Biology 68 (1990): 1344-51.

35. Tobias Kiene. The Legal Protection of Traditional Knowledge in the Pharmaceutical Field. Münster: Waxmann Verlag, 2011, p. 16.

36. Robert Svoboda. Ayurveda: Life, Health, and Harmony. London and New York: Arkana, 1992, pp. 299-303.

37. Narayan Patel. "Ayurveda: The Traditional Medicine of India." In Folk Medicine: The Art and Science. Edited by Richard Steiner. Washington: American Chemical Society, 1986, pp. 41-66.

38. Phyllis Balch. Prescription for Herbal Healing. New York: Avery, 2002, p. 26.

39. Daniel Sliva. "Ganoderma lucidum (Reishi) in Cancer Treatment." Integrative Cancer Therapies 2 (2003): 359-64.

40. The Huffington Post UK. "Skin Cancer Treatment: Liquorice Root May Fight Malignant Melanoma." The Huffington Post, 10 October 2013. Available online: http://www.huffington post.co.uk/2013/10/10/liquorice-root-may-fight-skin-cancer_n_4075898.html (accessed on 5 September 2014).

41. James Lovelock. The Ages of Gaia: A Biography of Our Living Earth. Oxford: Oxford University Press, 1988, p. 206.

42. Thomas Csordas. "The Sore That Does Not Heal: Cause and Concept in the Navajo Experience of Cancer." Journal of Anthropological Research 4 (1989): 457-86.

43. Adam Sowards. United States West Coast: An Environmental History. Santa Barbara: ABC-CLIO, 2007, p. 19.

44. Kathleen Hefferon. Let Thy Food Be Thy Medicine: Plants and Modern Medicine. Oxford: Oxford University Press, 2012, pp. 21-22. 
45. Monica Montopoli, Riccardo Bertin, Zheng Chen, Jenny Bolcato, Laura Caparrotta, and Guglielmina Froidi. "Croton lechleri Sap and Isolated Alkaloid Taspine Exhibit Inhibition against Human Melanoma SK23 and Colon Cancer HT29 Cell Lines.” Journal of Ethnopharmacology 144 (2012): 747-53.

46. Daniel Robinson. Confronting Biopiracy: Challenges, Cases and International Debates. London: Earthscan, 2010, p. 1.

47. Vandana Shiva. Biopiracy: The Plunder of Nature and Knowledge. New York: South End Press, 1997.

48. Darrell Posey. "Commodification of the Sacred through Intellectual Property Rights." Journal of Ethnopharmacology 83 (2002): 3-12.

49. Daniel Moerman. Native American Ethnobotany. Portland: Timber Press, 1998, p. 13.

50. Detlef van Vuuren, Osvaldo Sala, and Henrique Pereira. "The Future of Vascular Plant Diversity under Four Global Scenarios." Ecology and Society, 2006. Available online: http://www. ecologyandsociety.org/vol11/iss2/art25 (accessed on 5 September 2014).

(C) 2014 by the author; licensee MDPI, Basel, Switzerland. This article is an open access article distributed under the terms and conditions of the Creative Commons Attribution license (http://creativecommons.org/licenses/by/4.0/). 